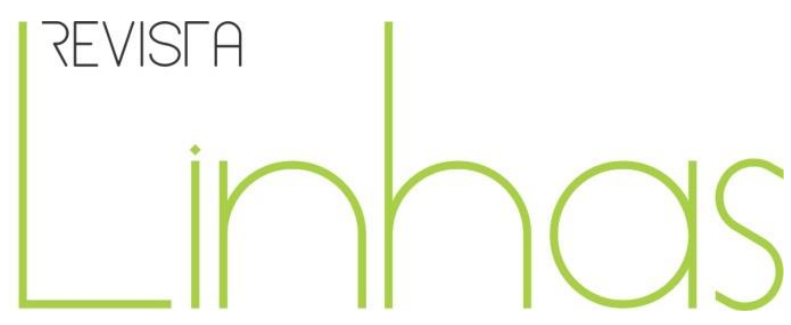

\title{
Sarau Janelas Floridas: (re)existências na educação e na arte
}

\section{Resumo}

Tomamos as Janelas Floridas, do concurso para Sarau de (Re)existência com a força da arte, como elemento provocador e potência de luta pela Educação Pública com cotidianos escolares contra os processos de gentrificação dos espaços urbanos. O que podem a alegria, a brincadeira e os afetos contra a aniquilação do capital? O Sarau Janelas Floridas surge nessa resposta, usa a arte para fortalecer a luta contra a construção de um shopping que ameaça a estrutura física e a existência da E. M. Dr. Álvaro Alberto, a Regional de Meriti, ou a Escola Mate com Angu. Expressão das vozes e experiências da escola e atores da sociedade civil que se reúnem num grito, num choro, num riso, numa explosão de alegria. O movimento do Sarau Janelas Floridas desenhou a experiência como trajeto de singularização. Nascido da mobilização da educação e da arte e de diferentes instâncias, sujeitos e instituições e acolhido pela comunidade escolar como movimento, se produz como acontecimento. Tomamos, no plano da ação, a experiência segundo Dewey, ao afirmar a via estética como concretização de uma tensão existencial, um ato efetuado e consumado de ações e percepções que permitem uma singularidade: aquele acontecimento, aquele dia que não se perde na dispersão dos fluxos do vivido. No plano das reflexões, recorremos a Benjamim e seu conceito de experiência como constituição política, o ato de contar a sua história é efetuá-la novamente e, ouvir a narrativa, o ato de incorporar ao repertório do vivente uma nova saída, uma escapatória, uma porosidade.

Palavras-chave: educação pública; arte; experiência; acontecimento e narrativa.

\section{Luciana Pires Alves}

Universidade do Estado do Rio de Janeiro - UERJ - Rio de Janeiro/RJ Brasil

lualpires@gmail.com

\section{Vanusa Rodrigues da Silva \\ Fundação Getúlio Vargas - FGV - Brasil \\ vanusadasilva@gmail.com}

\section{Para citar este artigo:}

ALVES, Luciana Pires; SILVA, Vanusa Rodrigues da. Sarau Janelas Floridas: (re)existências na educação e na arte. Revista Linhas. Florianópolis, v. 22, n. 50, p. 191-214, set./dez. 2021. 


\title{
Sarau Janelas Floridas: (re)existences in education and art
}

\begin{abstract}
We take the path of Janelas Floridas from the competition to Sarau de (Re)existence Janelas Floridas to show the strength of art as a provocative element and intensifying the power of struggle for Public Education with everyday school life against the gentrification processes of urban spaces. What can joy, play and aesthetic affections do against annihilation by capital? Sarau Janelas Floridas appears in the adventure of this answer, as it uses art and affection to strengthen the fight against the construction of a shopping mall that threatens the physical structure and existence of EM Dr. Álvaro Alberto, always Regional de Meriti and, in popular memory, always Escola Mate com Angu. Expression of the voices and experiences of the school and other civil society actors that come together in a scream, a cry, a laugh, in the powerful explosion of joy. Affirming Sarau Janelas Floridas as an experience is possible through the path of singularization that its movement has designed. Born from the mobilization of education and art and managing different instances, subjects and institutions and welcomed by the school community as a movement, Sarau is produced as an event. We take, in the action plan, experience according to Dewey, when affirming the aesthetic way as the realization of an existential tension, as an act carried out and consummated of actions and perceptions that allow a singularity: that event, that day that is not lost in the dispersion of flows of the lived. In terms of reflections, we turn to Benjamin and his concept of experience as a political constitution and the act of telling his story is doing it again and listening to the narrative, the act of incorporating a new way out, an escape, into the living being's repertoire, a porosity.
\end{abstract}

Keywords: public education; art; experience; event and narrative. 
A imaginação é a memória que enlouqueceu.

(Mário Quintana, 2005)

O coração está dentro, bordejado, delimitado.

Tem seus limites, que têm uma história.

A corda está fora.

(Deligny, 2015)

O presente artigo procura narrar o Sarau Janelas Floridas como experiência formativa e política através da arte e da alegria como modos de resistir aos avanços do capital através das práticas de gentrificação dos espaços. A reestruturação dos espaços urbanos, segundo os interesses do capital, é um dos modos de fazer negócio do capitalismo mundial integrado. Através da ótica da mercadoria, os lugares e todos o que lá habitam se tornam alvo do rentismo de uma economia de mercado (SMITH, 2007). A requalificação urbana, fruto dessa fome de lucros especulativo, é uma fonte de embates no campo social, principalmente dos agentes do patrimônio e dos sujeitos sociais que defendem a preservação ambiental. Esse é o contexto que faz emergir o Sarau Janelas Floridas; um movimento artístico de protesto que luta para proteger a E. M. Dr. Álvaro Alberto dos interesses do capitalismo. Idealizado pela sociedade civil - coletivo FORAS - é público e executado com a comunidade escolar.

Nosso trabalho de intervenção defende que os afetos alegres, as potências brincantes e a esfera do cotidiano escolar são elementos de enfrentamento e insurgência contra as investidas devoradoras do capitalismo. Nosso empenho se ocupa das menores coisas, das filigranas do cotidiano, incluindo as palavras a serem usadas; acreditamos na força das metáforas e no poder político das memórias; assim, buscamos a folia e não a guerra, a ludicidade e não a violência. Compreendemos nosso trabalho como a não cisão das dimensões empíricas e teóricas na construção de uma experiência ética e estética com o mundo. Para isso, defendemos alguns princípios ou pistas para elaborar e dar consistência ao nosso desejo.

Acordaram de nos aniquilar, de deixar a escola morrer à mingua, a cercaram por um deserto, o poder do dinheiro levou as gentes: vizinhos humanos, animais e vegetais. 
Violaram as árvores, sem as raízes, teias de fios que sustentam a nossa existência, parte da escola ruiu. O estrondo ainda se ouve até hoje, pelos cantos vazios pelas meias casas meias portas, meias varandas ao nosso redor.

Figura 1: Foto da destruição e abandono no entorno da escola

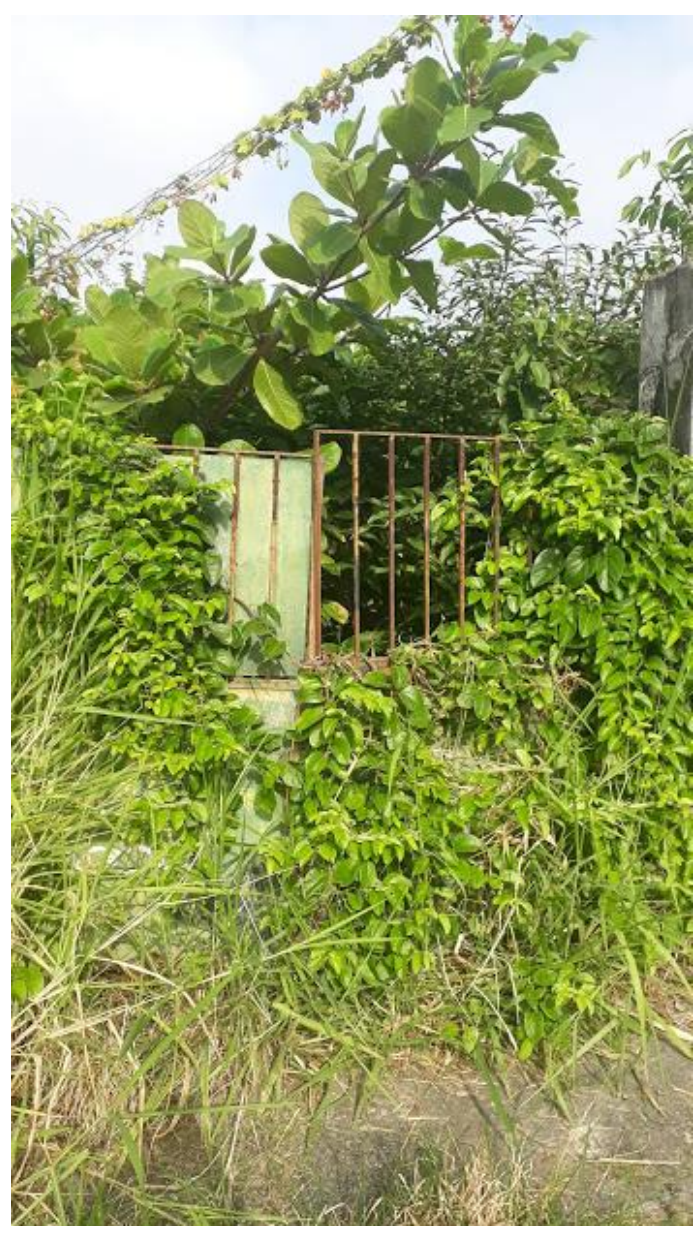

Fonte: Acervo Sarau Janelas Floridas.

E do lado de dentro da experiência devassada, "A gente combinamos de não morrer" (EVARISTO, 2018, p. 108) apesar do acordo maior do grande capital, o corpocoração da escola vibra em tons dissonantes e encontra no campo social outros corpos tocados pela eminência daquela destruição. 
Figura 2: O muro da escola desmoronado

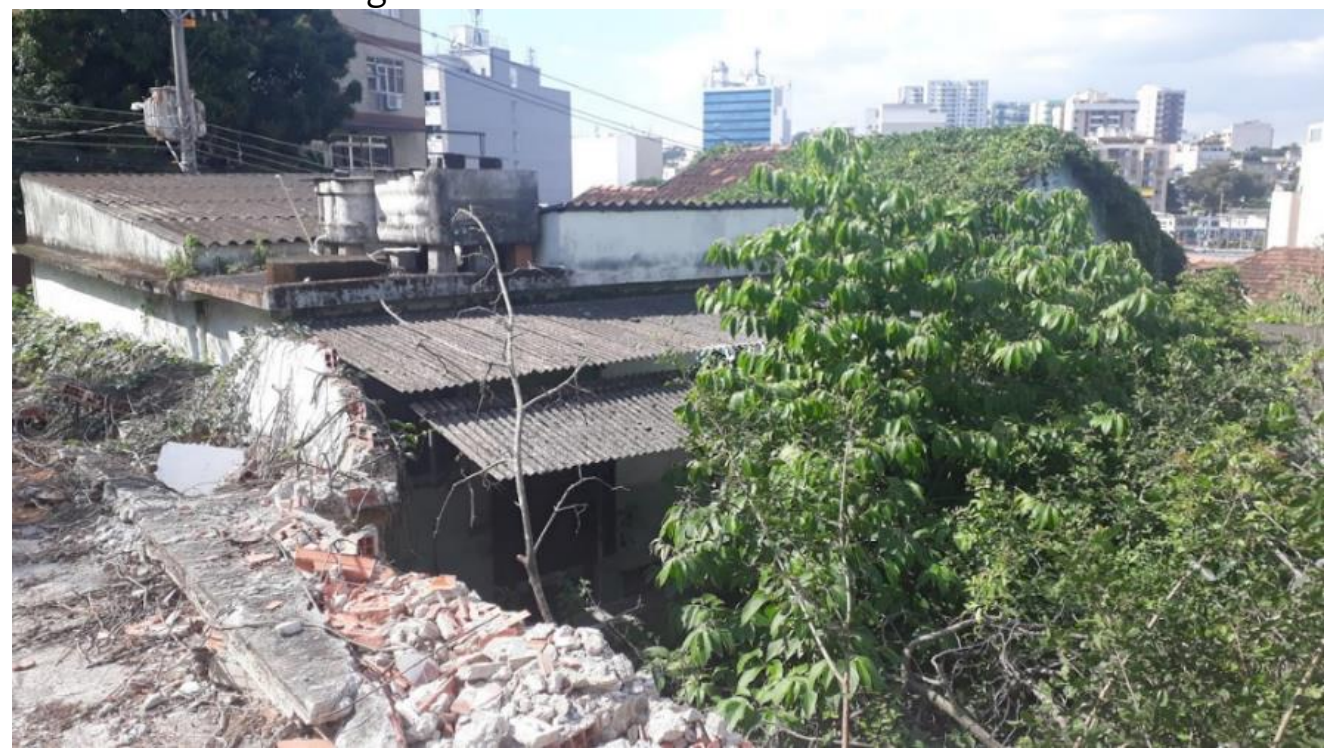

Fonte: Acervo Sarau Janelas Floridas.

Figura 3: Resistir é preciso (árvore da resistência)

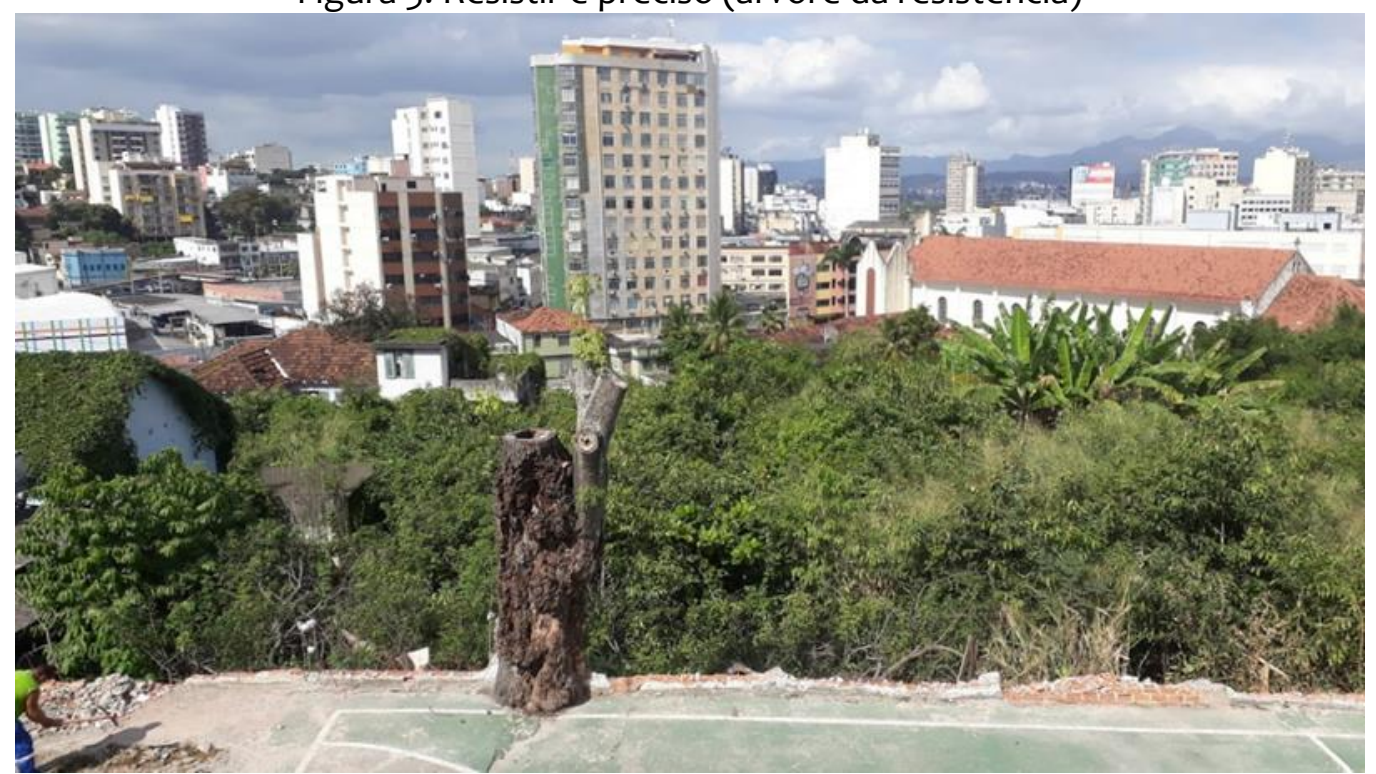

Fonte: Acervo Sarau Janelas Floridas. 
E, no limiar da destruição, nós, Flores de todas as cores, nascidas em janelas tão bem cuidadas para um concurso ${ }^{1}$, mulheres que somos, trouxemos a festa e a memória. Junto à luta coletiva dos diversos atores sociais, o Sarau surge do FORAS - Fórum de Oposição e Resistência ao Shopping - formado por diversas representações da sociedade civil organizada de Duque de Caxias, com o objetivo de lutar pelo direito à cidade. Shopping esse que seria construído no terreno ao lado da escola e criaria um deserto de capital em volta da educação afetiva que Armanda Álvaro Alberto plantou. Mas da memória coletiva aliada ao elemento ativador da brincadeira se constituiu uma arte de (re)existir, evocamos que um saber viver pela força de outrem requer trabalho e empenho de recriação, como afirma. "Os deuses, como diz Paul Valéry, nos dão de graça o primeiro verso." (SORIAU, 2020, p. 48). O tenro e tépido material trazido de cor, a memória e a imaginação se mesclam. Do ato ao sonho as existências virtuais que efetivam um real.

Vivo e pulsante axé de nossa sobrevivência: cordão umbilical de tantas lutas. Nossos umbigos são vestígios da corda pulsante que um dia tivemos e não mais, porém podemos acessar a sensação de compartilhar vital a partir de dentro, que este texto narrativo se propõe a falar. Das conexões, ligações e encruzilhada, onde nos mantemos vivas, como afirma Augé: “Certamente, Legba (Exu) baliza as vias da relação com outrem. Mas, é muito notável que, em sentido inverso, o próprio corpo de cada indivíduo esteja marcado pela presença de outrem. Legba é o umbigo do homem.” (AUGÉ, 1989, p. 69).

O corpo-coração do Sarau Janelas Floridas é a Mate com Angu. De sua natureza imiscuída, surge como um dos elementos da memória cultural da escola e da história da Regional de Meriti. Nossa miscelânea brincante produz outra inscrição no social para as Janelas Floridas, que passam de concurso saneador a um dia festivo, Sarau.

Das tantas formas de resistir, escolhemos a folia. Entregues a um estado de "folgança ruidosa", encontramos um modo de existência que rechaça a guerra, as metáforas e referências militares. Num mundo doente de guerra, como afirma Mbembe (2020), buscamos a afecção da alegria. Para nos manter neste estado ou mesmo para

\footnotetext{
${ }^{1}$ O concurso Janelas Floridas foi criado por Armanda Álvaro Alberto como competição entre alunos para escolher qual teria a janela mais bem cuidada. Embora tenha sido acusado de prática saneadora do ambiente, foi uma ação necessária no período em que surgiu, quando era preciso despertar o cuidado de si e dos lares no combate às muitas mazelas que acometiam os alunos e suas casas.
} 
chegar a ele, buscamos o exercício da palavra que rechaça a guerra e todas suas palavras de ordem explícitas e implícitas na linguagem (DELEUZE; GUATTARI,1995). A palavra opera no explícito do falar e nas dimensões que subtendem os trajetos, forças incorpóreas que agem no campo social.

Um sonhar coletivo de re-existir emerge da luta pela criação de outros mundos possíveis e viáveis. Diferimos das perspectivas teórico-políticas da essência humana, com as mãos nuas até de nosso destino (GUATTARI, 2013) e nos encafuamos em sonhos, conversas e cantorias para adiar o fim do mundo (KRENAK, 2020). Ao nosso redor, ainda habita o deserto produzido pela empresa ABL Shopping ${ }^{2}$ e pelo descaso do poder público. Restos de casas, fachadas destruídas, calçadas quebradas e fios soltos. Apenas e somente elas, as plantas ressurgem e o verde retoma a paisagem como quem acolhe e sustenta as produções humanas. O sonho dos sobrados de comércios, as casas, os muros baixos e a vizinhança foram substituídos pela boca voraz do capitalismo do rentismo parasitário, de quem aposta com a vida dos outros na mesa de carteado. As autoridades municipais que se permitem ao jogo da especulação, mais se parecem com a imagem criada por Baudelaire: “A derradeira moeda à mão de um jogador.” (BAUDELAIRE, 2006, p. 1994).

\section{2- Era uma vez uma escola que ganhou de um shopping}

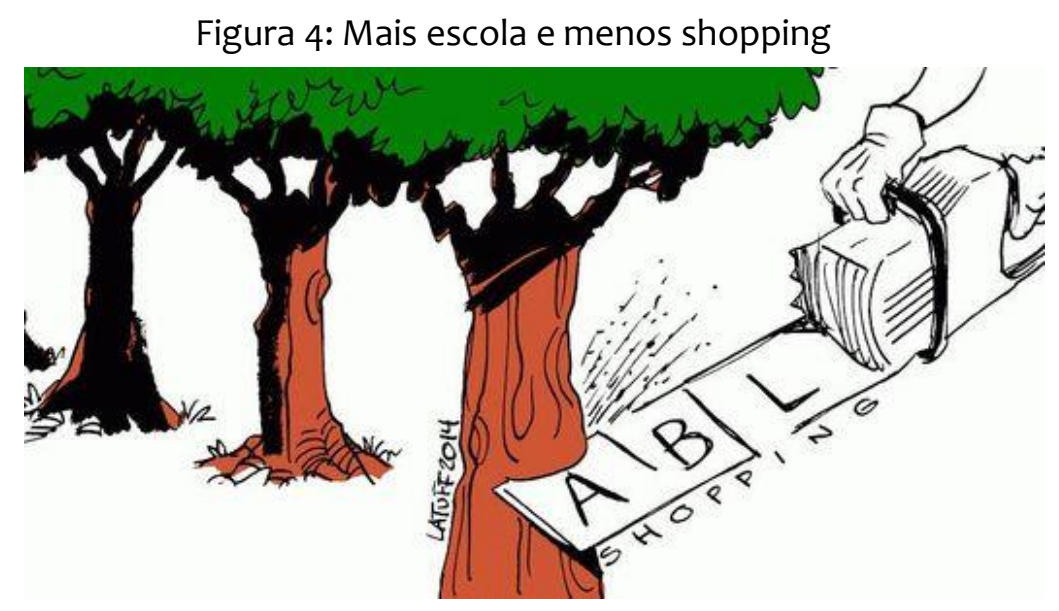

Fonte: https://www.facebook.com/Foras-Caxias-1662640850676056/

\footnotetext{
${ }^{2} \mathrm{ABL}$ - Área Bruta Locável Construtora - empresa de construções responsável pela implantação do shopping ao lado da escola.
} 
Em "Metáfora viva", Ricoer (2001) abriu ao uso das metáforas o poder de referenciar a narrativa através da união entre mitos e mimese. Assim, as metáforas permitem acessar esse intervalo de realidade e sonho. No exercício de seu poder do que era e não era, as metáforas nos permitem mais do que descrever a realidade. Possuem o poder de recriar o que trazemos na memória e a sua escolha é referência para a ação e para a narração. Numa condição de brincantes e amadores, buscamos nos orientar no prumo da folia e da diacronia. Essa ação narrativa se inicia pela via da transposição possibilitada pelas metáforas; buscamos as referências brincantes e não as referências bélicas; permanecemos como corpos em combate, porém amantes da alegria e não da destruição e dos afetos tristes, ao ter como arena análoga que inunda de afetos e imagens nosso fazer e nosso pensar.

As metáforas são nossos transportes coletivos que nos levam ao destino desejado ou apenas indicado, como afirma Certeau (1994) sobre os relatos de espaço. Resolvemos tomá-las como vias de mão dupla, uma vez que ao ter uma arena análoga e ao informar, trazem os modos de existir de seus lugares referidos. Ao nos dispormos de forma distinta das metáforas militares para representar e organizar nossa resistência no interior da escola, escapamos da sensação de trincheira e da desgraça de habitá-la. Também, rompemos com as imagens militares, cujo regime de representação é majoritário em nossa sociedade que ensina, desde muito cedo, que o poder é o exercício da violência.

Para alimentar a utopia de uma sociedade brincante, conjuramos a guerra, ali onde eram esperados campos de batalhas, explosões de cólera e ódio, devolvíamos carnaval, abraçamos árvores, grafitamos tapumes, aprendemos a fazer Slam e a ouvir histórias de outros tempos. Era uma vez, uma escola que se recusa a ceder seu lugar a um shopping. Era uma vez um prédio, o primeiro considerado patrimônio histórico da Cidade de Duque de Caxias, que resiste a dar seu lugar a um templo do consumo. Era vez um espaço verde, um respiradouro e um refrigério para o calor e o vapor da cidade, que foi ser apagado do mapa, teve suas copas e raízes pisoteadas pelas máquinas de fazer dinheiro. Mas as raízes (re)existem!

“Era uma vez" essa expressão mágica, essa palavra-passe que nos permite entrar no reino da brincadeira, na festa. A potência brincante também é o escândalo da arte, daqueles que se debatem contra a indiferença dos destinos. Narrar e brincar se equivalem 
quando há uma necessidade de sobrevivência, como afirma Massumi (2017): "O gesto lúdico é um gesto vital” (2017, p. 21). A escrita do presente artigo se encontra impregnada dessa ação; ao pôr em palavras, sou revisitada pela recordação dessa experiência brincante de re-existir, que a conexão com a miudagem permite. Formas menores de resistência ao produzir uma política pulsante e alegre, porém não menos eficazes.

\title{
3- A pulsação política de um coração vagabundo
}

\author{
Meu coração não se cansa \\ De ter esperança \\ De um dia ser tudo o que quer \\ Meu coração de criança \\ Não é só a lembrança \\ De um vulto feliz de mulher \\ Meu coração vagabundo \\ Quer guardar o mundo \\ Em mim \\ (Caetano Veloso, 2002)
}

A esse ponto, gostaria de perguntar: onde a função docente se ancora? Nos ideais religiosos, nos discursos civilizatórios, nas tarefas revolucionárias, nas esperanças de modernização e no desenvolvimento científico. Tantos são os portos e as passagens vividas pela experiência docente que parece louca e fantástica a ancoragem na alegria e no mar aberto da arte. Não se trata, como adverte Guattari (1992) a respeito da psicanálise, de estetizar o campo da docência, mas sim de nos aproximar do que há de rico, de criativo, de inventivo, do que já está em movimento de devir. E, nessa postura aberta ao Outro, enquanto mundo possível, é que passamos a nos ligar às crianças e ao que elas trazem fora de todos os preenchimentos culturais que o mundo dos adultos já construiu.

E, nos deixar mover e entrar em devir outro, ao experimentar na atividade brincante o entusiasmo no corpo ou os afetos de vitalidade que nos reconectem com os movimentos barrados e cessados pelo mundo codificado da cultura. Para, assim, virar a chave, "trocar o disco" para encontrar as "palavras-desde-a-desordem" que nos afirmem a vida e não a pulsão de morte recorrente à sociedade brasileira. Trocar o rumo, mudar a 
rota, vivenciar de fato uma experiência que nos afaste do fosso e da pulsão por precipitar abismos e que ative o desejo de viver.

É Guattari que aponta Fernand Deligny como catalisador desse desejo e, da experiência em Cevennes, como a invenção de uma circunstância potente no agenciamento de uma economia coletiva que permitiu que as pessoas vivessem juntas. Essa junção, essa ligação que ganha destaque no trabalho de Deligny, que defende que nossa atuação, como uma presença próxima da criança, autista ou não. A proximidade e a leveza defendidas por Deligny apontam para a errância brincante ou vagabundagem eficaz, como aponta o autor:

Quando o povo for libertado e ousar andar com seus próprios pés, a obra de arte ganhará para ele formas, cores e músicas familiares. Será preciso, por favor, libertar ao mesmo tempo as crianças e colocá-las junto de educadores de presença leve, provocadores de alegria, sempre prontos a remodelar bolas de argila, vagabundos eficazes maravilhados pela infância. (DELIGNY, 2018, p. 130)

Para a função docente, a ancoragem na arte engendra uma linha de fuga das formas determinadas e úteis ao capitalismo tardio no regime $24 / 7^{3}$ e em tempos do pósmídia tão importantes para as lógicas da gentrificação. Entendemos, como Crary (2016), que o capitalismo engendra uma temporalidade vivida como um looping infinito de rede social numa dinâmica de produção e consumo, cuja última barreira é o sono. Sem o limite que o olho no olho ou a chamada à responsabilidade que o rosto do outro nos impõe, as ideias de reestruturação dos espaços, de criminalização dos sujeitos periféricos e a maledicência sobre os lugares circulam livremente e uma mentira repetida muitas vezes ganha status de verdade e essas produções são essenciais para a concretização das ambições da gentrificação. Bem como o meio das produções semióticas atuais, depois do acúmulo das manchetes e da tarefa de manter-se informado, a chave muda no pulular das telas e dos conteúdos que chegam. A sobrevivência da escola exigiu um jogo de

\footnotetext{
3 Jonathan Crary, em 24/7 Capitalismo Tardio e os fins do Sono (2016), delimita o modo atual de produzir o tempo. A temporalidade, sem demarcações fixas que não separa o trabalho, o lazer e o consumo, cria um tempo homogêneo, cuja palavra de ordem é produzir e consumir, todos os "likes" e desejos são transformados em dados e mercadoria para as grandes empresas. Através da instrumentalização do desejo e da atenção qualquer intervalo é solapado pelo emprego da tecnologia wireless e pela mobilização das subjetividades. A última barreira para o 24/7 é, animal que somos, o animal que dorme. Dormir para sonhar, para pausar, para imaginar novos mundos. Tudo que o capitalismo tardio não quer.
} 
articulação com o tempo presente de nossas raízes reconfiguradas não só em redes sociais e digitais, como também a articulação com a sociedade civil organizada, a militância pelo patrimônio cultural e os grupos que lutam pela preservação do meio ambiente. É importante lembrar que o único espaço verde do centro da cidade de Duque de Caxias foi ceifado para dar lugar à obra de construção do Shopping, o que resultou em danos no muro e na quadra da escola.

\section{4- De raízes às redes: a dimensão coletiva da re-existência}

Topando em imagens desde há muito sonhadas.

(Baudelaire, 1995)

A Escola Regional de Meriti é um lugar povoado por sonhos; topamos, como diz Baudelaire, em muitos deles pelo espaço físico e pelo espaço social. O sonho ou a imagem propagada pela escola “Mate com Angu” mobiliza diferentes elementos do campo social. Do sonho ao ato, a ameaça à escola para dar lugar ao shopping, acendeu as conexões das memórias populares sobre a escola, o que alternou o modo de sustentação da escola. No lugar dos enraizamentos institucionais, as redes de relações nos tempos e nos espaços da educação, da cultura e dos movimentos sociais.

A trajetória de sobrevivência e resistência da escola me permite afirmar que dentre os princípios defendidos pela professora Armanda Álvaro Alberto, a relação com a comunidade foi a que mais frutificou. Entre eles estão:

[...] se desejava transformar em modelo para o projeto de educação popular do país, na medida em que a escola partilhava dos princípios da escola ativa, partindo do interesse da criança, respeitando os diferentes ritmos de aprendizagem, estimulando o contato com a natureza e defendendo a integração da escola com a comunidade. (MIGNOT, 2010, p. 51)

Presente no imaginário popular na cidade de Duque de Caxias, a "Mate com Angu" atravessa gerações. Sua ligação se faz sentir entre os diferentes grupos da cidade: professores, cineastas, militantes dos movimentos, os sujeitos envolvidos com esportes, 
políticos e imprensa local, não há quem não tenha alguma recordação direta ou uma memória recebida sobre a escola. Os envolvimentos que fizeram do Concurso Janelas Floridas o Sarau são revelares da permanência do desejo e do trabalho de professora Armanda de que "Como se vê, a escola tem lançado raízes profundas no seu meio social." (ALBERTO, 2010, p. 164).

Dos frutos fortes, temos a experiência do Sarau Janelas Floridas que reúne diferentes atores da cena cultural, educacional e política da cidade de Duque de Caxias. A força e a potência de singularização. O concurso Janelas Floridas surge inicialmente em 1923, como umas das diferentes ações de mobilização e intervenção na paisagem de Meriti, como afirma Armanda:

Se a feição de escola-casa de família, baseada na liberdade, no trabalho individual, nos hábitos de saúde, na alegria com que se desempenham as funções domésticas, se essa face evidenciou-se desde os primeiros dias, a outra, de ação na vida local, direta, essa foi surgindo a partir do $3^{\circ}$ ano de existência da escola, com o $1^{\circ}$ concurso de "Janelas Floridas", em 1923. São notórios a indolência, o descaso por tudo que não seja $o$ estritamente necessário ao seu viver de incultos, sem uma parcela de intuição na arte de aformosear a vida, entre os nossos roceiros. Combater a fealdade e o desconforto de Meriti, dar-lhe alegria das flores e a sombra das árvores, tais são os fins visados pela iniciativa da escola. A princípio, só os alunos floriram suas janelas; depois, a população foi concorrendo também, sendo distribuídos, em 1920, 64 prêmios dos quais 26 aos moradores. Casas construídas recentemente já apresentaram nas janelas jardineiras de cimento ou de madeira! Claro é que a Comissão julgadora das janelas floridas não concede prêmios àquelas desacompanhadas de um quintal bem tratado. E o gosto pelas plantas vai-se desenvolvendo [...]. (ALBERTO, 2010, p. 164)

A presente reflexão não pode negar ou passar ao largo do caráter higienista e preconceituoso quanto à paisagem local que, como seu povo, são alvos de constantes conversões e reconversões segundo as disputas nos meandros das forças políticas. Depois de tanta água passada por debaixo da ponte de Meriti, construída depois de muita insistência da professora Armanda, podemos compreender e interpelar o colonialismo impregnado nessas palavras e no próprio olhar sobre as periferias.

Assim, comemorar nosso primeiro centenário é rememorar a história do lugar social, dos lugares e das gentes que foram, como diz poeticamente, José Luandino Vieira 
(2007, p. 103) "lugares agredidos através da linguagem". Combater a fealdade de Meriti está vinculado à escolha política dos discursos sobre as periferias, se nos anos 1920 se comemoravam o centenário da independência e a melhoria, modernização e regeneração dos espaços eram palavras de ordem em nossa sociedade. A guinada regional contra a centralização nacional e o afastamento do atraso são marcas nem sempre rememoradas desse tempo, como afirma Santiago, em seu artigo sobre a Pauliceia de Mario de Andrade, na Folha de São Paulo, em 30 de maio de 2021. Nas palavras do autor:

O inédito agrupamento humano paulista será capaz de retirar o país das mãos da oligarquia rural, responsável atraso civilizacional que lhe vem sendo atribuído como fatalidade, seja pelo passado colonial genocida e escravocrata, seja com vistas ao futuro pós-colonial. Santiago, Folha de São Paulo, 30 de maio de 20201. (ANDRADE, ano, p. xx)

Mesmo guardando as diferenças e distâncias entre os grupos políticos e intelectuais, vemos que a crítica ao atraso e ao abandono emerge desse lugar de construir uma trajetória de contraposição ao velho e ao atrasado. E, entre disputas e modos de narrar e ver os lugares agredidos, a afirmação da carência e da potência ainda gera problemática. Mesmo quando escolhemos ver e afirmar o que temos e não o que nos falta, não podemos cair em negação das mazelas deixadas por um passado colonial, genocida e escravocrata.

Assim, cabe o exigente exame das formas de exercício da memória: o comemorar e o rememorar, não sendo possível festejar nosso primeiro centenário sem rememorar nossas dores e lutas. Segundo Ricoeur (2003), o primeiro diz respeito à repetição e à fixação dos conteúdos na memória coletiva, comemorar uma data, um acontecimento, uma personalidade, possuindo como meio de ação, um festejo, um monumento, uma data no calendário. Já o rememorar se refere a um exercício mais aberto que depende de trazer à memória novamente o acontecido consigo ou com os outros, sujeito ao corpovivência e às impressões e reflexões compartilhadas.

Ainda em Ricoeur (2003), quando rememorar e comemorar se correspondem, há um exercício abusivo da memória, que, nesse caso, fica a serviço da repetição dos lugares sociais estabelecidos pelos mais privilegiados. Para o autor, a rememoração é um 
trabalho de elaborar uma representação do passado contra a compulsão de repetição. Também, é um exercício político contra os abusos da memória coletiva e dos modos de estabelecer os vínculos sociais.

O comemorar da Mate com Angu não está restrito à marca da merenda escolar, como gosta o governo local. A merenda escolar e os demais saberes e ações da ordem da vida prática compõem o projeto de aprendizagem ativa defendido por Dona Armanda e seus companheiros de Escola Nova. O abuso da memória que recorta e torna a enquadrar a educação pública apenas como a escolarização dos mais necessitados ainda ganha destaque; basta ver as manchetes comemorativas de nosso centenário e a fala oficial do prefeito Washington Reis. A manchete do jornal O Dia, de 24 de fevereiro de 2021, destaca: “Escola 'Mate com Angu' completa 100 anos em Duque de Caxias. Unidade municipal foi a primeira da América Latina a servir merenda escola”. Abaixo, a declaração oficial do prefeito:

- Aqui, surgiu a merenda escolar. Servimos a primeira refeição gratuita em uma escola da América Latina, com uma professora muito comprometida e que entendeu que uma criança também precisa de educação pela boca. Diante disso, uma criança bem alimentada é um aluno que terá uma melhor performance na aprendizagem. (O DIA, 2021)

\section{5- Os percursos do Sarau como experiência - filigrana e miudagem}

Defendemos o percurso do Sarau como experiência segundo o delimitado por Dewey (2010), em sua obra Arte como experiência. Segundo o autor, ter uma experiência obedece a algumas especificidades. Entre elas está nossa capacidade de identificar entre os fluxos das vivências, aquele material que pode ser destacado em particular, uma vez que ele não se perde na dispersão ou na evaporação displicente. Em sua distinção como experiência, o fluxo vai de algo para algo, como ensina Dewey (2010). A singularidade do fluxo da experiência é marcada por uma composição rítmica própria sem centralidade única ou tempos mortos, cuja vitalidade não sacrifica a identidade singular das partes. Nas palavras do autor: 
Por causa da fusão contínua, não há buracos, junções mecânicas nem centros mortos quando temos uma experiência singular. Há pausas, lugares de repouso, mas eles pontuam e definem a qualidade do movimento. Resumem aquilo porque se passou e impedem sua dissipação e sua e evaporação displicente. (DEWEY, 2010, p. 111)

Além da origem, do destino e da composição múltipla do fluxo, a experiência se distingue também por uma unidade que lhe confere um nome ou uma qualidade ímpar. Segundo Dewey (2010), ter uma experiência, implica não apenas passamos por algo, mas quando algo nos passa. Essa singularidade nos permite, ao recordar, falar daquele acontecimento em especial. E, a natureza da experiência pode ser mais propriamente expressa pela arte, o estético assume um papel essencial, por ser a esfera em que o indivíduo pode "discernir uma relação particular entre o agir e o suportar em relação ao todo que deseja produzir" (DEWEY, 2010 p. 124).

A arte não é um supérfluo, algo a ser dispensando diante de outras dimensões tidas como mais importantes como a ordem prática e utilitária, o conhecimento científico ou até mesmo a organização da luta e da resistência.

Figura 4: Preparando o carnaval literário do Sarau 1 - 2019

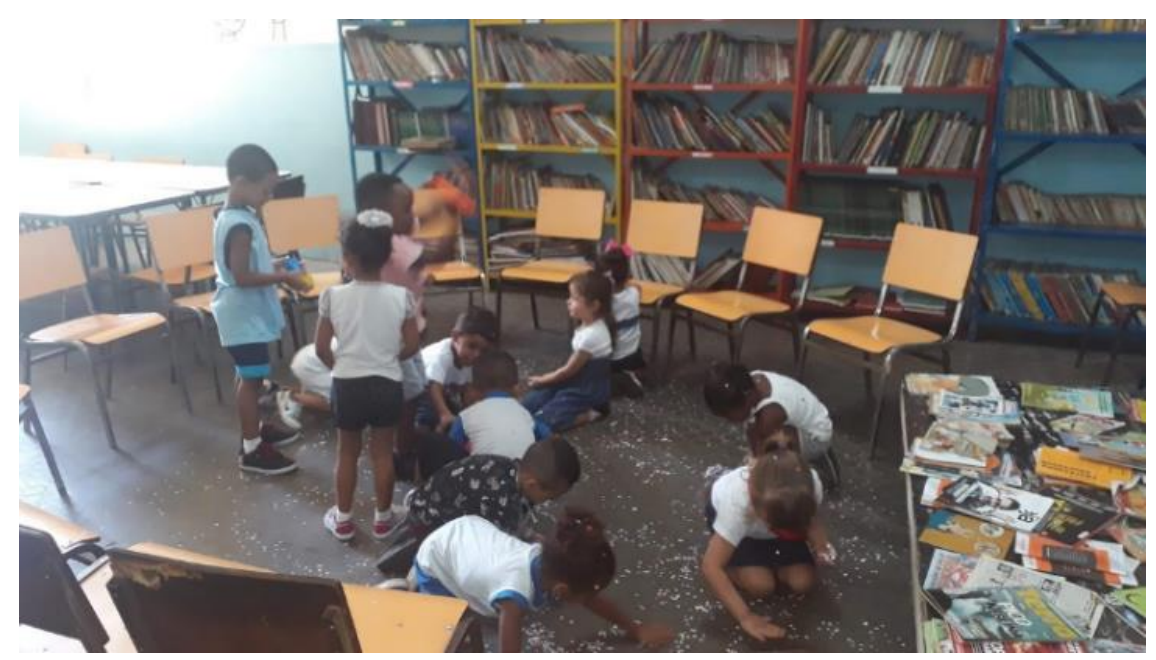

Fonte: Acervo Sarau Janelas Floridas. 
Figura 5: Preparando o carnaval literário 2 - 2019

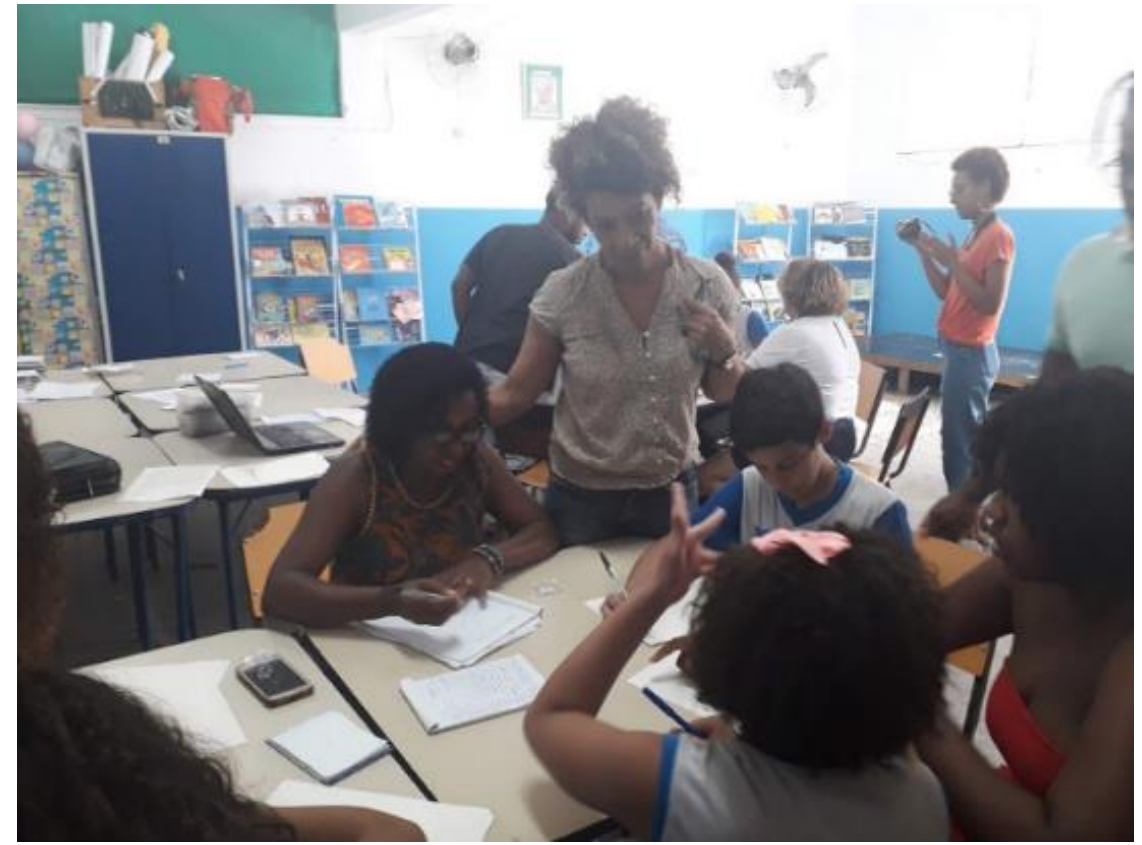

Fonte: Acervo Sarau Janelas Floridas.

Figura 6: Sr. Hélio (Helinho) e o "standart" confeccionado para o carnaval literário

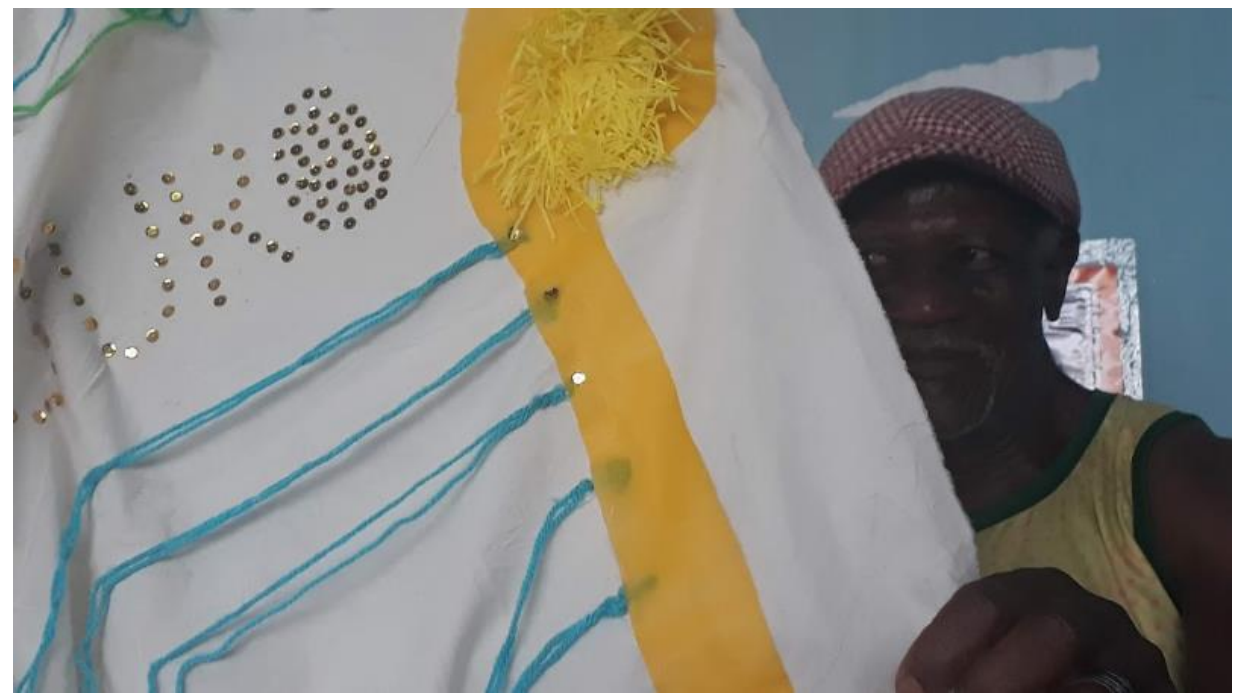

Fonte: Acervo do Sarau Janelas Floridas.

Engajar as práticas pedagógicas num paradigma ético estético é nos aproximar das vias de re-existências audíveis, visíveis e tangíveis. O fazer estético entre as crianças e as professoras cria um lugar de proximidade, um modo singular de habitar a escola. Não só do dia do Sarau em si, mas tudo o que o antecede nos permite práticas moleculares alternativas ao conceito maior de escola, de aula, de ser docente e de ser aluno. Ler, 
desenhar, conversar, brincar, carnavalizar gestos que gradualmente se tornam naturais, o que nos torna mais próximos da arte, dos conceitos e da filosofia e nos distancia da violência, tão banalizada em nosso espaço.

Afirmamos as potências inventivas nas mil histórias trazidas pelas crianças sobre suas casas, suas vidas, seus corpos, seus sonhos, dúvidas e medos. Tudo isso são modos de refratar os podres poderes: "Enquanto os homens exercem seus podres poderes. Morrer e matar de fome, de raiva e de sede. São tantas vezes gestos naturais." (Podres Poderes, Caetano Veloso). Na dimensão do cotidiano da escola, decidimos velar pela alegria do mundo. Lá, onde foi naturalizada a dor e a morte, buscamos com nossas bolhas de sabão insuflar uma esfera de proteção e alegria através da apreciação das obras artísticas, da comoção literária, da força poética e musical dos versos de nossa MPB. Aqui, onde tantas conversões e reconversões foram operadas e outras tantas entraram em disputa, buscamos acionar o gatilho para o agir artístico, como aponta Dewey:

A arte denota um processo de fazer ou criar. Isso tanto se aplica às belasartes quanto às artes tecnológicas. A arte envolve moldar a argila. Entalhar o mármore, fundir o bronze, aplicar pigmentos, construir edifícios, cantar canções, tocar instrumentos, desempenhar papéis no palco, fazer movimentos rítmicos da dança. Toda arte faz algo com algum material físico, o corpo ou alguma coisa externa a ele, com ou sem o uso de instrumentos intervenientes, e com vistas à produção de algo visível, audível ou tangível. (DEWEY, 2010, p. 127)

O fazer cotidiano com as crianças requer o mergulho na matéria por elas trazida para que o agir coletivo nos leve à experiência de superação do mero reconhecimento gerado pelos clichês que circulam pela sociedade e impedem uma mais apurada percepção do mundo. A relação da criança com a arte, força fundamental da pedagogia ativa defendida por Armanda, é retomada por nós como meio de inventar uma escapatória. E traçar essa relação foi o elemento operante de nossas práticas de pesquisas com os cotidianos. Não se trata de afirmar que as crianças fazem arte, isso não é de responsabilidade delas, mas sim de criar circunstâncias e um ambiente para a experimentação dos meios e de receptividade ativa do patrimônio artístico.

O desenho de Richard surgiu a partir da leitura coletiva de "Velho atabaque", de Solano Trindade, e da oficina de Toque de Ataque. Através da leitura, da escuta e do 
aprender a tocar, Richard afirma que o som do atabaque traz para ele: amor, paixão, companheirismo, amizade, carinho, união, reunião e alegria.

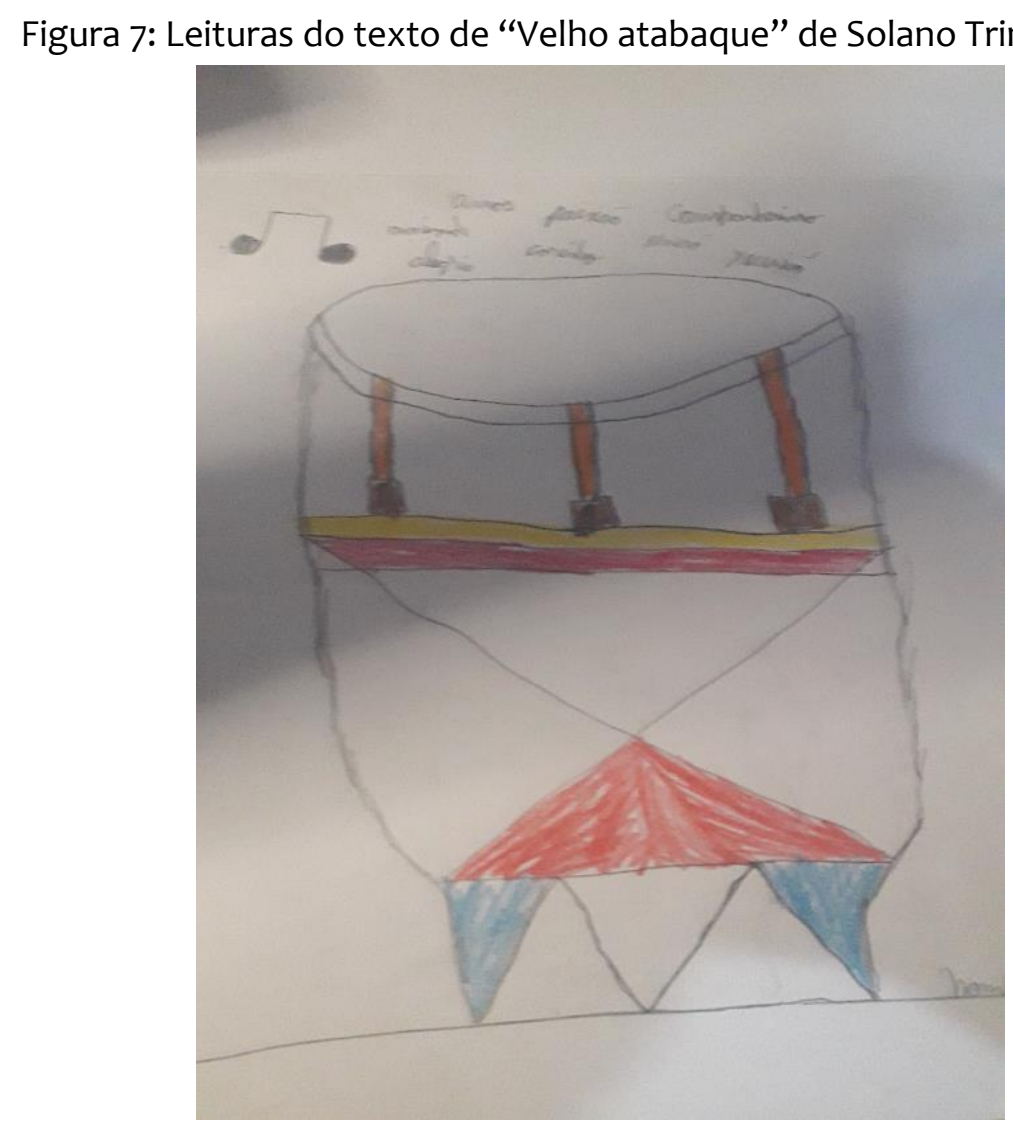

Fonte: Acervo Sarau Janelas Floridas.

Figura 8: As crianças e o velho atabaque

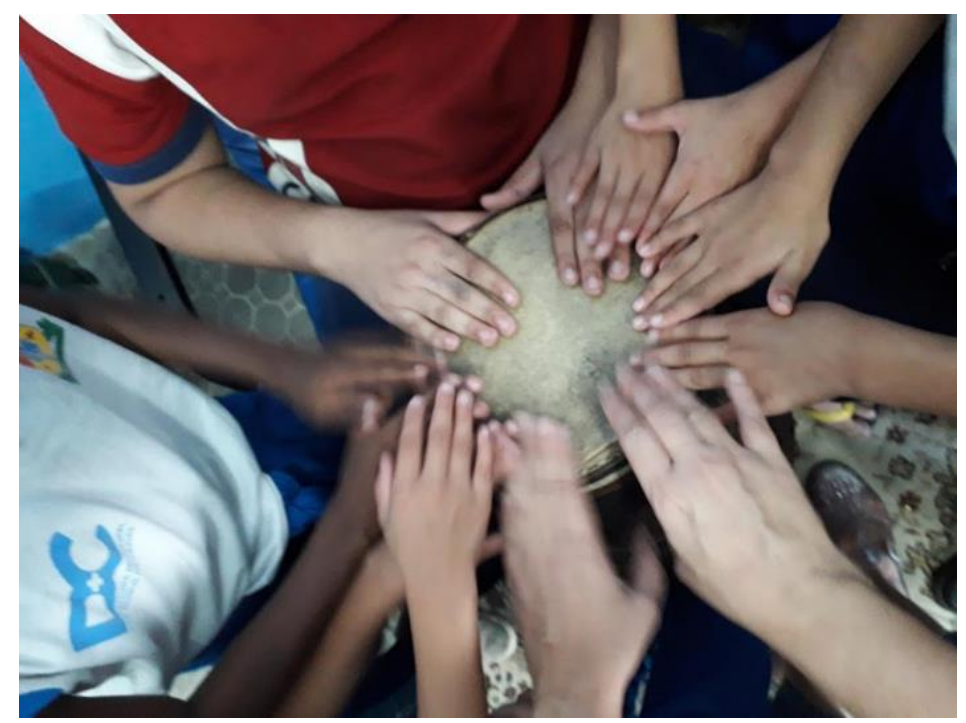

Fonte: Acervo Sarau Janelas Floridas. 
A receptividade ativa da obra de arte, como definido por Dewey (2010), dialoga com o identificado por Benjamin como alteração das condições de receptividade da poesia e da mudança da estrutura da experiência causada pelo surgimento e avanço da imprensa, do romance, da fotografia e da possibilidade de reprodução da técnica da obra de arte.

A possibilidade da distração através do entretenimento recobre e se impõe diante da experiência da percepção (BENJAMIN, 2017). Seguimos mais pelo mero reconhecimento que Dewey adverte e pela relação massificada com a obra de arte que Benjamin denuncia. Ambas as atitudes são inimigas da experiência, aquela que nos comove, emociona ao nos fazer pensar e perceber o que se passa. A separação e a ampliação do distanciamento entre informação e o antigo relato, baseado na experiência, foram processos decisivos para a produção em massa do desejo e a fabricação dos modos de subjetividade. A reprodutibilidade técnica e as formas de sociabilidade baseadas na cultura de massa dos meios urbanizados foram decisivas para a propagação de um ideal de educação livresca e passiva, tão contrária às tentativas de liberdade, escola ativa de um fazer e experimentar direto com o mundo.

Ao buscar o fluir vivo da experiência, não inauguramos nada de novo em nossa escola; o Sarau Janelas Floridas se apresenta como ápice e pretexto para a retomada no cotidiano com as crianças é esse o espírito de fruição e sonho. O Sarau, como prática de resistência brincante, nos remete à infância da própria escola e nos permite também relativizar, conversar e problematizar os modos de viver a infância no presente. Como o trabalho de leitura e mergulho coletivo na poesia de Solano Trindade, "Bolinhas de Gude", no poema, o autor narra a desventura de Jorginho, menino preto da periferia vulnerável à criminalização e à violência de Estado.

\author{
Bolinhas de Gude \\ Jorginho foi preso \\ quando jogava bolinha de gude \\ não usou arma de fogo \\ nem fez brilhar sua navalha \\ Jorginho era criança igual às outras \\ queria brincar \\ O brinquedo poderia ser um revólver
}


uma navalha

um pandeiro

quem sabe um cavalinho de pau

Jorginho queria brincar

Jorginho viu um filme americano

no outro dia

fez uma quadrilha de mentirinha

sempre brincando

a quadrilha foi ficando de verdade

Jorginho ficou grande como Pelé

todos os dias saía no jornal...

Televisionado

só não deu autógrafo

porque estava algemado

Ele era o facínora

que brincava com bolinhas de gude.

(TRINDADE, 1981, p. 40)

Figura 9: Leitura de Luan do texto "Bolinhas de gude" de Solano Trindade

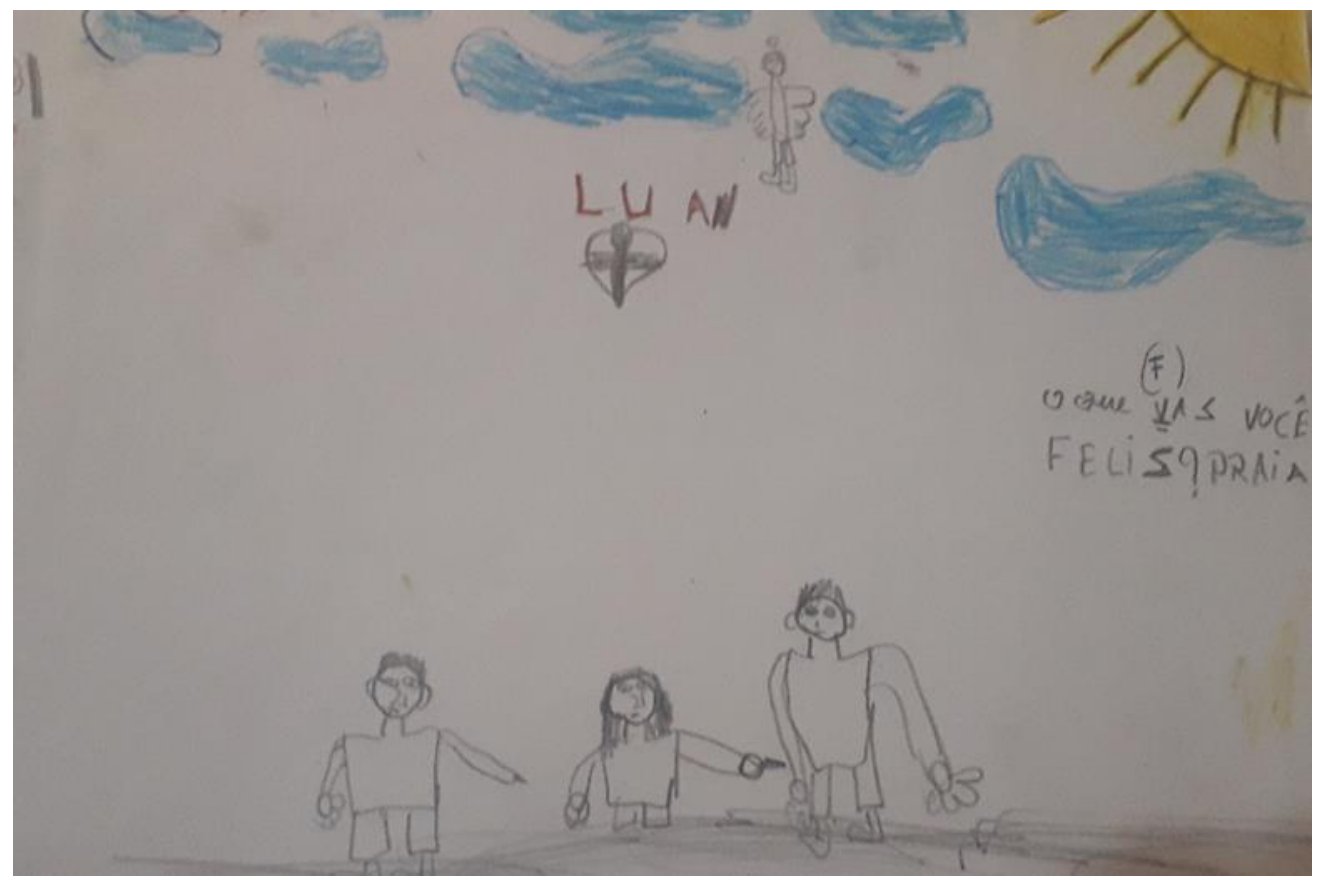

Fonte: Acervo Sarau Janelas Floridas. 


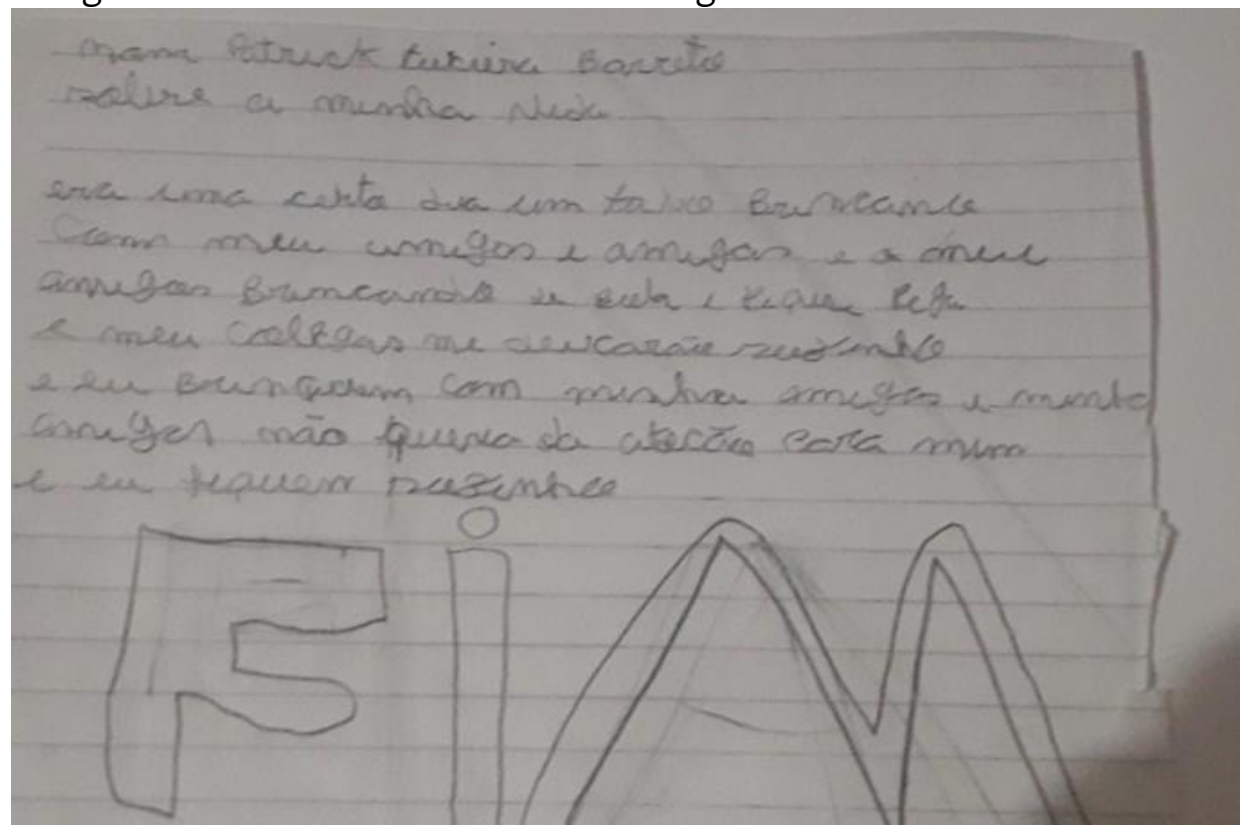

Fonte: Sarau Janelas Floridas.

\title{
Conclusão
}

\author{
Bombas na guerra, magia \\ Ninguém matava \\ Ninguém morria \\ Nas trincheiras da alegria \\ O que explodia era o amor \\ Nas trincheiras da alegria \\ O que explodia era o amor
}

Composição: Abel Silva / Moraes Moreira, 1981)

O Sarau Janelas Floridas recorda um movimento visceral da pulsação política do desejo. Ao desnudar o coração, pulsa o entrelace das forças: a memória, a infância e a prática docente. A narrativa feita de matéria viva e que faz viver no pulsar: relações de frequência e vibração da alteridade; do coração e da corda: os acordes acordados para resistir contra quem traz o peito esvaziado pela captura do capital: trazer a infância como experiência de aprender, na escola, a resistir contra quem combinou de nos matar e a prática docente como invenção na potência da alegria, dos sonhares coletivos. 
A defesa do trabalho de memória como um ato político e estético que envolve nos gestos os atos de comemorar, rememorar e recordar. Atos esses que são responsáveis pela instauração de um vínculo social e que lapidam o veio de onde afluem o fluxo da memória. O que recordamos nos vem, muitas vezes do representado pelas palavras e nem sempre pelo vivido diretamente, daí a importância do trabalho de memória e narrativa contra a compulsão pela repetição do que circula na memória coletiva, como nos ensina Ricoeur (2003). Quais forças se confrontam pela direção da memória? Quais as razões que enquadram o que contamos? Quem soterra e quem escava? Sabemos de antemão que "Todo Carnaval tem seu fim", investimos e ficamos com o que resta. O que sobra da folia não é lixo, é resistência. Restar é resistir, como nos ensinou Agamben (2016).

O Sarau Janelas Floridas é feito assim, desses tempos acavalados. Palimpsestos feitos de presenças descontínua, entre cada camada, o que resta é a resistência do fluxo dos acontecimentos e consideramos vestígios dos diferentes tempos. Das políticas sanitárias de enquadramentos das classes e dos espaços populares como potencialmente educáveis para e pelo mundo do trabalho; da sanha devoradora do rentismo e da especulação; da presença da infância criminalizada e matável das periferias urbanas, das pessoas da escola, nossos sonhos, cores e desejos... A dimensão da luta nas trincheiras do cotidiano com o veio diário de gestação do Sarau e a guerra a céu aberto, do Foras. O dentro e o fora da escola, na luta, o que mostra que as dimensões diferentes não são antagônicas ou precisam funcionar segundo um ordenamento hierárquico. A luta, a festa, a prática e a teoria educativas se engajam com a arte e seu potencial para o viver, que em tempos e em políticas de morte, é o tudo que nos resta! 


\section{Referências}

AGAMBEN, Giorgio. $\mathbf{O}$ tempo que resta: um comentário à carta aos romanos. Belo Horizonte: Autêntica, 2016.

AUGÉ, MARC. O fetiche e seu objeto: abordagem etnológica. In: AUGÉ, Marc et al. 0 objeto em psicanálise: o fetiche, o corpo, a criança, a ciência. Campinas: Papirus, 1989.

BAUDELAIRE, Charles. Poesia e prosa: volume único. Rio de Janeiro: Nova Aguillar, 1995. BENJAMIN, Walter. Estética e sociologia da arte. Belo Horizonte. Autêntica editora, 2017.

CERTEAU, Michel de. A invenção do cotidiano. Petrópolis: Vozes, 1994.

CRARY, Jonathan. Capitalismo tardio e os fins do sonho. São Paulo: UBU Editora, 2016.

DELEUZE, Gilles; GUATTARI, FÉLIX. Mil Platôs: capitalismo e esquizofrenia. 2. São Paulo: Ed. 34, 1995.

DELIGNY, Fernand. Os vagabundos eficazes: operários, artistas, revolucionários: educadores. São Paulo: N-1 edições, 2018.

DELIGNY, Fernand. O Aracniano e outros textos. São Paulo: N-1 edições, 2015.

DEWEY, John. A arte como experiência. São Paulo: Martins Fontes, 2010.

EVARISTO, Conceição. Olhos d'agua. Rio de Janeiro: Pallas, 2016.

GUATTARI, FÉLIX. Líneas de fuga: por outro mundo de posibles. Cuidad Autónoma de Buenos Aires: Cactus, 2013.

KRENAK, Ailton. A vida não é útil. São Paulo: Companhia das Letras, 2020.

O DIA. Escola 'Mate com Angu' completa 100 anos em Duque de Caxias, 2021. Disponível em: https://odia.ig.com.br/duque-de-caxias/2021/02/6091735-escola-mate-com-angucompleta-100-anos-em-duque-de-caxias.html. Acesso em 30 out. 2021.

MASSUMI, Brian. O que os animais nos ensinam sobre política. São Paulo: N-1 edições, 2017.

MBEMBE, Achille. Necropolítica: biopoder, soberania, estado de exceção, política da morte. São Paulo: N-1 edições, 2018.

MIGNOT, Ana Chrystina Venancio. Viajar para legitimar: Armanda Álvaro Alberto na Comissão de Intercâmbio Brasil-Uruguai (1931). Revista Brasileira de História da Educação, cidade, n. 22, p. 43-64, jan./abr. 2010. 
MIGNOT, Ana Chrystina Venancio. Armanda Alberto. Recife: Fundação Joaquim Nabuco,

Editora Massangana, 2010. (Coleção Educadores).

QUINTANA, Mário. Sapato florido. São Paulo: Globo, 2005.

RICOEUR, Paul. La metáfora viva. Madrid: Ediciones Trotta, 2001.

RICOEUR, Paul. La memoria, la historia, el olvido. Madrid: Ediciones Trotta, 2003.

SOURIAU, Étiene. Diferentes modos de existência. São Paulo: n-1 edições, 2020.

SANTOS, André da Rocha. Revitalização para quem?: política urbana e gentrificação no centro de Santos. Caderno Metrópole, São Paulo, v. 16, n. 32, p. 587-607, nov. 2014. Dossiê: desenvolvimento desigual e gentrificação da cidade contemporânea.

TRINDADE, Solano. Cantares ao meu povo. São Paulo: Editora Brasiliense, 1981.

VIEIRA, José Luandino. A cidade e a infância: contos. São Paulo: Companhia das Letras, 2007.

Recebido em: 22/06/2021

Aprovado em: 18/08/2021

Universidade do Estado de Santa Catarina - UDESC Programa de Pós-Graduação em Educação - PPGE Revista Linhas

Volume 22 - Número 50 - Ano 2021 revistalinhas@gmail.com 